\title{
Responsabilidade do Transportador por Via Aérea
}

\author{
Professor Antônio Chaves
}

Catedrático de Direito Civil da Faculdade de Direito da Universidade de São Paulo

\section{Transportes aéreas}

Sem embargo da semelhança que sob alguns aspectos possa apresentar com o transporte por terra e por água, a expansão comercial da aviação patenteia que os princípios da responsabilidade civil insertos no CC manifestam-se insuficientes para a solução dos problemas que surgem, exigindo a estruturação da responsabilidade do transporte aéreo segundo princípios próprios.

Para compreender-se a matéria é preciso remontar a mais de meio século atrás, quando as empresas de aviação não haviam assumido ainda o poderio e o desenvolvimento que as caracteriza nos dias de hoje.

Os riscos eram então enormes, não só para os passageiros e as cargas, como também para os operadores de vôo, tripulação, e para os empresários, que tinham que investir quantias vultosas em empreendimentos dos mais arriscados.

A aplicação dos cânones da responsabilidade civil comum, ao lado do retraimento das companhias seguradoras, implicaria fatalmente num atraso desse fator de desenvolvimento.

Sentiu-se então necessidade de uma atenuação do rigor, principalmente por meio de cláusulas contratuais que diminuíam ou isentavam o transportador por via aérea da obrigação de indenizar, nos casos de acidente, como fez a Lei francesa de 1924.

Instituído pelo Decreto-lei no 483, de 08-06-1938, o primeiro Código Brasileiro do Ar. com 173 artigos, consagrou à matéria da responbilidade três capítulos, revogou o art. 84 do Regulamento dos Serviços

* Parte da palestra proferida no dia 05-10-81, na $5^{9}$ Semana de Estudos de Direito Civil, do Departamento de Direito Civil da Faculdade de Direito da Universidade de São Paulo. 
Civis da Navegação Aérea, de 22-07-1925, que mandava aplicar os dispositivos do $\mathrm{CC}$ aos casos de prejuízos causados por uma aeronave, a fim de apurar a responsabilidade do piloto e do armador, no caso, os arts. 1088, 1056 e 1059 CC.

Foi substituído pelo vigente Decreto-lei $\mathrm{n}^{\circ} 32$, de 18-11-1966, com emedas pelo Decreto-lei $\mathrm{n}^{\circ} 234$, de 28-02-1967 e pela Lei $\mathrm{n}^{\circ} 6.350$, de 07-07-1976.

Seus 165 artigos estão distribuídos em 13 títulos: I. Introdução (arts. $\left.1^{\circ}-7^{\circ}\right)$; II. Das Aeronaves ( $\left.8^{\circ}-28\right)$; III. Dos Tripulantes (29-42); IV. Da Infra-estrutura Aeronáutica (43-79); VII. Do Transporte Aéreo (80-121); IX. Das Garantias de Responsabilidade (122-127); X. Do Abalroamento Aéreo (128-133); XI. Da Assistência e do Salvamento (134-149) ; XII. Da Decadência (150-152) e XIII. Das Infrações (153161), com quatro Disposições Finais.

Mas o transporte aéreo é, por vocação, insofrido de fronteiras, não tardando reuni-se, em Paris, em 1925, uma Conferência Internacional de Direito Privado Aéreo, realizando-se em 1929, após longos trabalhos preliminares, uma segunda Conferência.

OCTANNY SILVEIRA DA MOTTA, O Dolo do Transportador Aéreo face à Lei Internacional e ao Código Brasileiro do Ar, Rev. dos Tribunais, vol. 356, 1965, págs. 46-57, encarece que, sob o ponto de vista único da responsabilidade civil, a Convenção trouxe vantagem clara para as empresas de transporte aéreo, permitindo-lhes conhecer antecipada e precisamente a extensão dos montantes de indenização devidos, cobrindo-os através de seguro.

De outro lado, o passageiro ou seus sucessores que perdem, eventualmente, a possibilidade de se ressarcirem da totalidade do dano sofrido, são colocados pela Convenção, em contrapartida, ao abrigo de quaisquer cláusulas de exoneração e vêm erguer-se em seu benefício, presunção de culpa do transportador.

Foi preocupação marcante e visível do legislador convencional estabelecer equilíbrio entre as posições de usuário e transportador. $\mathrm{E}$ procura de equilíbrio em termos semelhantes aos do atingido na lei internacional veio a marcar a lei brasileira, modelada naquele padrão.

É sob esse ângulo - o de seu papel no esquema de proporcionalidade pretendido - que encara e interpreta os dispositivos que, na Convenção de Varsóvia e no Código Brasileiro do Ar. aludem ao dolo.

Cuidemos dos Capítulos que dizem respeito ao nosso tema, a começar pelo da Responsabilidade Contratual, versada nos arts. 97-109, do Decreto-lei $\mathrm{n}^{\circ} 32$, cujos textos analisaremos já com as modificações das leis posteriores.

Nos termos do art. 97, caput, responde o transportador por qualquer dano resultante de acidente relacionado com a aeronave em vôo ou na superfície, a seu bordo ou em operação de embarque ou desem- 
barque, que causar a morte ou lesão corporal do passageiro, salvo culpa deste, sem culpabilidade do transportador ou de seus prepostos.

Qual será o fundamento dessa responsabilidade? AGUIAR DIAS - localiza na culpa presumida, ao passo que, para ALVINO LIMA, teria natureza contratual, afirmando que a própria Lei assim o diz, sob o título "Responsabilidade Contratual".

$\mathrm{Na}$ verdade será de natureza contratual, quando decorra do contrato; provirá, de culpa presumida, podendo ser ilidida, quando o inadimplemento da obrigação de conduzir o passageiro são e salvo ao seu destino tiver ocorrido por culpa exclusiva deste.

O transportador responde pelo dano resultante de destruição, perda ou avaria da bagagem despachada ou de carga, nos acidentes ocorridos durante o transporte aéreo (art. 98), que compreende, para tais efeitos, o período durante o qual a bagagem ou a carga se acharem sob a guarda do transportador, em aeródromo, a bordo da aeronave ou em qualquer outro lugar (art. 99).

Exclui o art. 100, do transporte aéreo, o transporte terrestre ou aquático realizado fora do aeródromo, mas se na execução do contrato do transporte aéreo for executado transporte terrestre, marítimo ou fluvial para o carregamento, entrega ou baldeação, presume ocorrido o dano durante o transporte aéreo, salvo prova em contrário.

O transportador responde ainda pelo dano resultante de antecipação ou de atraso do transporte aéreo do passageiro, da bagagem ou da carga, salvo caso de força maior inclusive os impostos pela segurança do vôo, cabendo-lhe a prova de tal circunstância (art. 101).

Tivemos oportunidade de assinalar, Responsabilidade pré-contratual, pág. 26, que o transporte, em geral há de ser feito nas condições e nos horários estabelecidos: o público conta com aquela determinada condução no momento certo; a alteração, sem prévio aviso, podendo ocasionar detrimento, transtornos, perda de tempo, dá margem a indenização. Para que a empresa possa alterar os horários sem vir a ser eventualmente responsabilizada, terá que levar ao conhecimento do público, pelos meios ao seu alcance, essa modificação, assim como a eventual impossibilidade em que venha a se encontrar, por força maior, de satisfazer os compromissos assumidos perante o público.

Por outro lado, a própria Lei cuida de tarifar a indenização devida pelo transportador.

O parágrafo único do mesmo art. 101 limita-o, nesse caso, em se tratando de passageiro, pelo máximo de $10 \%$ do valor dos prejuízos provados, e, nos demais casos, pelo máximo de $10 \%$ do valor respectivo da bagagem ou carga transportada.

"Art. 102. Se a viagem sofrer interrupção em aeroporto de escala por tempo superior a seis horas, qualquer 
que seja o motivo, o transportador é obrigado à instância do passageiro, a fazê-lo reembarcar incontinenti para o destino pelo meio mais rápido possível e que ofereça idêntico ou melhor serviço, correndo por conta do transportador contratual todos os gastos inclusive os de hospedagem, decorrentes de interrupção, sem prejuízo das responsabilidades estabelecidas no artigo anterior."

O sistema, da mesma forma que o convencional, baseia-se nos princípios da presunção de responsabilidade do transportador, da limitação dessa responsabilidade e da proibição de cláusulas contratuais que tendam a excluir a responsabilidade ou fixá-la aquém dos montantes legalmente estabelecidos.

$\mathrm{O}$ art. 103 do Código do Ar estabelece que no transporte de passageiros, salvo se for convencionada indenização mais alta, a responsabilidade do transportador por qualquer dano resultante da morte ou lesão corporal de passageiro será limitada por pessoa, à importância correspondente a 200 vezes o maior salário-mínimo vigente no País.

Elevou, assim, embora ainda em base absolutamente insuficiente, o teto que a Lei $\mathrm{n}^{\circ}$ 4.221, de 08-05-1963, alterando o art. 91 do anterior Código do Ar, fixava em 150 vezes o referido maior salário.

Também o CC português traça limites máximos de indenização nos casos de acidente de viação e nos de danos causados por instalações de energia elétrica ou gás (arts. 508-510).

\section{Responsabilidade para com terceiro}

É matéria objeto dos arts. 109 a 127, abrangendo quaisquer aeronaves, públicas ou privadas, nacionais ou estrangeiras, em vôo ou manobras de partida ou de chegada, em território brasileiro (art. 109), que causem dano a pessoas ou a bens, que se encontrem no solo ou em águas jurisdicionais brasileiras, bem assim o originado por pessoas ou coisas dela caídas ou projetadas, inclusive pelos alijamentos resultantes de força maior; não, entretanto, o dano que não for conseqüência direta do fato causador ou que ocorrer em virtude da operação normal da aeronave, realizada de conformidade com as normas recomendadas (art. 110).

Foi o caso do avião Navajo que no dia 24-03-1979 simplesmente "entrou" no apartamento de Mirian Gomes da Silva, no $15^{\circ}$ andar do Edifício Marajó, à rua Gabriel Rezende Passos, bairro de Moema, S. Paulo, aí deixando dois grandes rombos e as laterais chamuscadas pelo incêndio. Pediu ela, na ocasião, dois milhões e meio de indenização pelos prejuízos sofridos.

A responsabilidade se estende aos danos produzidos pela queda de corpo caído da aeronave, mesmo quando se trate de lastro regu- 
lamentar, ou de outras coisas alijadas por necessidades técnicas, e as provocadas por atos de pessoas que se encontrem a bordo. Neste caso, serão solidariamente responsáveis o dono ou explorador da aeronave e a pessoa que, de bordo, haja causado o dano.

Cuida-se, aí, da responsabilidade extracontratual, adotando-se os princípios da teoria objetiva como fundamento do dever de reparar; existe uma correspondência entre este e o art. $1.529 \mathrm{CC}$, relativo ao dano proveniente de objetos caídos ou lançados de uma casa, sendo mais explícito o Código do Ar quanto à definição dessa responsabilidade.

Considera o art. 112 a aeronave em vôo ou em manobra, a partir do momento em que é empregada a sua força motriz e até que, cessada esta, tenha fim o movimento próprio, aplicando-se à aeronave desprovida de força motriz a expressão "voo" ou "manobra" ao período compreendido entre o início e o fim de seu movimento.

Manda o art. 113 sejam regulados pelo direito comum os danos causados pela aeronave no solo e com motores parados.

$\mathrm{O}$ art. 114 subordina a responsabilidade pelo dano causado a terceiros na superfície, por outrem que não o explorador ou tripulantes da aeronave, à legislação comum, mas não exclui a responsabilidade limitada do explorador, prevista no Código do Ar.

Sujeita o art. 115 a responsabilidade pelo dano causado a terceiros na superfície, por quem utilizar a aeronave sem o consentimento do explorador, à regra do art. 110, mas não exclui a responsabilidade limitada do explorador, prevista no mesmo Código, que, no entanto, ficará elidida se provar que exerceu a devida vigilância para impedir o uso ilegítimo da aeronave.

“Art. 116. Qualquer das pessoas responsáveis terá direito à ação regressiva contra o autor do dano.

Art. 117 Os danos causados a pessoas na superfície serão indenizados pelo explorador, observado nos casos de morte ou incapacidade e estabelecido no art. 103, acrescido de 50\%."

Se duas ou mais aeronaves em vôo colidem ou se em suas evoluções perturbarem uma a outra, e daí resultarem danos pessoais a terceiros que dêem direito à indenização, nos termos do art. 110 ou se duas ou mais aeronaves causarem conjuntamente esses danos, cada uma delas será considerada pelo art. 118 como tendo causado o dano, e os respectivos exploradores serão responsáveis nas condições e limites estabelecidos no Código, tendo, nestes casos, a pessoa que sofrer os danos ou os seus beneficiários direito a ser indenizados, até a soma dos limites correspondentes a cada uma das aeronaves, mas nenhum explorador será responsável por soma que exceda os limites aplicáveis às suas aeronaves, salvo se sua responsabilidade for ilimitada, nos termos do art. 121. 
O dano pode ser pois produzido pela colisão de duas aeronaves em vôo, ou em movimento, devendo-se, nesse caso, distinguir-se o dano sofrido por passageiro, por terceiro, na superfície do solo, considerado nesse dispositivo, ou pelas aeronaves que se abalroaram, objeto dos arts. 126 a 132.

Pelo dano sofrido por um passageiro, a responsabilidade da empresa é contratual, presumindo-se a sua culpa, mas ficando-lhe salvo o direito de regresso contra o responsável pela outra aeronave, no caso de culpa do piloto desta.

A responsabilidade pelo dano causado a terceiros na superfície está sujeita à regra do art. 119, sendo simplesmente objetiva.

Responde pelo dano a aeronave que diretamente o produziu, não lhe valendo a escusa de ter sido a colisão provocada por outro avião, porque, segundo aquela regra, sua responsabilidade se exclue, ou atenua, por culpa do lesado.

Caberá, porém, ação regressiva contra o responsável pelo avião, que tenha provocado o abalroamento.

Se ambas as aeronaves causaram o dano sofrido pelo terceiro na superfície, responderão solidariamente por ele as respectivas empresas. Se não se puder estabelecer qual das aeronaves, que se chocaram, produziu o dano na superfície, dividir-se-á a responsabilidade entre elas, em partes iguais.

No caso de danos a pessoas e bens na superfície, causados por aeronave brasileira, a indenização que será rateada, proporcionalmente aos prejuízos resultantes, obedecendo aos limites fixados no art. 119.

"Art. 120 Quando a importância total das indenizações fixadas exceder o limite da responsabilidade estabelecida neste Código, aplicar-se-ão as regras seguintes, tendo-se em conta o disposto no art. 117:

a. as indenizações, no caso de morte ou lesão, ou então somente no caso de danos materiais, serão reduzidas em proporção aos seus respectivos montantes;

b. se as indenizações se referirem tanto ao caso de morte ou lesões como aos danos materiais, a metade da importância total a ser distribuída destinar-se-á, de preferência, a cobrir as indenizações por morte ou lesões, e, se for insuficiente, deverá ser rateada proporcionalmente ao montante respectivo dos danos causados. O saldo da importância total a ser distribuído será rateado, proporcionalmente, entre as indenizações relativas aos danos materiais e, se for o caso, à parte não coberta das indenizações por morte ou lesões."

“Art. 121. A pessoa responsável não se poderá prevalecer dos limites fixados neste Código, se o interessado provar que o dano foi causado por dolo." 
Em qualquer dessas hipóteses, fica salvo o direito à ação regressiva ao que pagou a indenização, contra o causador do dano, se posteriormente se reconhecer unilateralidade da autoria ou culpa pelo evento. A responsabilidade dos danos causados reciprocamente pelas aeronaves, que se choquem, é regulada, com fundamento na culpa.

\section{Do abalroamento aéreo}

Como tal define o art. 126 qualquer colisão entre duas ou mais aeronaves, em vôo ou em manobra na superfície, considerando prejuízos de abalroamento os danos causados por aeronave em vôo ou em manobra à outra aeronave também em vôo ou em manobra, mesmo que não resultem em colisão.

A responsabilidade pela reparação dos danos resultantes de abalroamento é atribuída pelo art. 129 ao explorador da aeronave comprovadamente culpada, quer a utilize pessoalmente, quer por preposto seu no exercício de suas funções.

Os prejuízos de abalroamento sujeitos a reparação são indicados no dispositivo seguinte:

a. os danos a pessoas e coisas a bordo da aeronave abalroada;

b. os danos sofridos pela aeronave abalroada;

c. os danos decorrentes da privação do uso normal da aeronave abalroada, correspondente aos lucros cessantes;

d. os danos que o explorador da aeronave abalroada for obrigado a pagar.

"Art. 131. Se a culpa for comum às aeronaves envolvidas em abalroamento, cada qual suportará os danos causados."

"Art. 132. A responsabilidade dos exploradores das aeronaves culpadas em caso de abalroamento, não excederá:

a. do dobro dos valores fixados neste Código para os casos de morte e les̃ões corporais de pessoas embarcadas, danos a mercadorias e bagagens despachadas, e a objetos sob a guarda pessoal de passageiros, a bordo de aeronave abalroada (art. 103);

b. de valor dos reparos e substituições de peças da aeronave abalroada, se recuperável, ou de seu valor real imediatamente anterior ao abalroamento, se inconveniente a sua reparação;

c. de $10 \%$ (dez por cento) do valor da aeronave abalroada, determinado em conformidade com o item anterior, por lucros cessantes, em virtude da privação do seu uso normal."

Mas o art. 133 ressalva não prevalecerem tais limites:

a. se o abalroamento resultar de dolo do explorador, ou de preposto seu, no exercício de suas funções; 
b. se a pessoa responsável pelo abalroamento se tiver apoderado ilicitamente da aeronave, dela fazendo uso sem o consentimento de quem tiver esse direito;

c. se o explorador da aeronave causadora do abalroamento tiver concorrido, por si ou por seus prepostos, para o evento, por ação ou omissão violadora da lei ou da regulamentação em vigor, seja o ato, comissivo ou omissivo, causa imediata ou mediata, do abalroamento.

Seguem-se normas relativas à assistência e ao salvamento, que obrigam o Comandante da aeronave a prestar assistência a quem se encontrar em perigo de vida no mar, no ar ou em terra, desde que o possa fazer sem perigo para a aeronave, sua tripulação, seus passageiros ou outras pessoas (arts. 134-140), reconhecida a todo resultado útil direito a remuneração correspondente ao trabalho e à eficiência do ato, nas bases que o art. 141 especifica:

a. Considerar-se-á, em primeiro lugar, o êxito obtido, os esforços, os riscos e o mérito daqueles que prestaram socorro; o perigo ocorrido pela aeronave socorrida, seus passageiros, sua tripulação e sua carga; o tempo empregado, as despesas e prejuízos suportados tendo em conta, quando ocorrer, a situação especial do assistente;

b. em segundo lugar, o valor das coisas salvadas.

Não haverá remuneração:

a. se o socorro for recusado ou se carecer de resultado útil;

b. quando o socorro for prestado por aeronave pública.

O proprietário ou armador do navio conserva o direito de se prevalecer do abandono, ou da limitação de responsabilidade fixada nas leis e convenções em vigor.

Todo aquele que, por imprudência, negligência ou transgressão, provocar a movimentação desnecessária de recursos de busca e salvamento ficará pelo art. 142 obrigado a indenizar a União pelas despesas decorrentes dessa movimentação, mesmo que não tenha havido perigo de vida ou solicitação de socorro.

"Art. 143. Prestada assistência sem obrigação de o fazer, aquele que a prestou somente terá direito à remuneração se obtiver resultado útil, salvando pessoas ou concorrendo para salvá-las."

"Art. 144. Cabe ao proprietário ou explorador indenizar a quem prestar assistência a passageiro ou tripulante da aeronave".

Se o socorro for prestado por diversas aeronaves, embarcações, veículos ou pessoas envolvendo vários interessados, a remuneração será fixada em conjunto pelo juiz, e distribuída segundo os critérios estabelecidos no art. 145, sem exceder o valor que os bens salvados tiverem no final das operações de salvamento (art. 146). 
Obriga o art. 147 ao pagamento da remuneração quem utilizar a aeronave sem o consentimento do proprietário ou explorador, que com ele responderá solidariamente se não tiver exercido a vigilância para impedir o uso ilegítimo da aeronave, podendo a remuneração ser reduzida ou suprimida se provado que os reclamantes tornaram necessário o socorro, concorreram para aumentar os prejuízos ou se tornaram cúmplices de furtos, extravios ou outros atos fraudulentos (art. 148).

Dá o art. 149 ao proprietário ou explorador da aeronave o direito de reter as cargas até ser paga a cota que lhe corresponde da remuneração da assistência ou salvamento, podendo o proprietário da carga retirá-la mediante caução suficiente ao pagamento.

\section{Da decadência}

Sob pena de decadência, os direitos decorrentes das relações jurídicas indicadas no art. 150 deverão ser exercidos dentro do prazo de dois anos, a contar das datas que especifica.

Se o interessado provar que não teve conhecimento do dano ou da identidade do responsável, o prazo de decadência começará a correr do dia em que disso tiver conhecimento, mas não ultrapassará de três anos a contar da data do evento.

A requerimento da parte ou "ex-offício" o juiz determinará integração da lide por todas as pessoas solidariamente responsáveis pelo dano, para efeito do direito regressivo (art. 150).

O direito de ação contra os construtores da aeronave decairá em cinco anos, a contar da entrega da aeronave.

O transportador é obrigado a conservar, pelo prazo de três (3) anos, as vias respectivas dos seus documentos de transporte aéreo (arts. 151 e 152).

\section{Danos decorrentes de defeitos mecânicos}

Merece atenta ponderação o art. 151 fazendo decair em cinco anos o direito de ação contra os construtores da aeronave.

O CC, no art. 94, define como omissão dolosa, nos atos bilaterais, o silêncio intencional de uma das partes a respeito de fato ou qualidade que a outra parte haja ignorado, provando-se que sem ela não se teria celebrado o contrato, e nos arts. 1101-1106 autoriza seja enjeitada a coisa recebida em virtude de contrato comutativo por vícios ou defeitos ocultos que a tornem imprópria ao uso a que é destinada, ou lhe diminuam o valor.

Mas quando uma pessoa é vítima de um acidente ocasionado por defeito no funcionamento de um maquinismo, ou sofra qualquer outro 
prejuizo, o que lhe interessa não será certamente invocar esses dispositivos, e sim obter uma indenização substancial dos danos sofridos.

$\mathrm{O} \mathrm{CC}$ italiano consagra à matéria norma expressa:

"Art. 2050. Responsabilidade pelo exercício de uma atividade perigosa. Aquele que ocasionar prejuízo a outrem no exercício de uma atividade perigosa pela sua natureza ou pela natureza dos meios adotados, ficará obrigado à indenização se não provar ter adotado todas as medidas para evitar o prejuízo."

Mas a doutrina se antecipa em deduzir semelhante princípio. Assim, ENRICO CATELLANI, Il Diritto Aereo, Milão, Bocca, já em 1911 realçava, a pág. 87, a importância do ordenamento jurídico da navegação aérea no que diz respeito às garantias relacionadas com a construção dos aviões e com o seu exercício, e a necessidade de disciplinar a liberdade de especulação a bem da segurança pública.

FEDERICO PEZZELA, La Responsabilità del Proprietario di veícoli negli Infortuni della Strada e dell'Aria, Roma, Società Editrice Libraria, 1935, depois de encarecer vigorarem as mesmas normas que governam o concurso de culpas, adita, a pág. 399, dever-se considerar, na conformidade da doutrina geral do direito, que mesmo a mínima observância das regras de conduta, produtiva de um fato previsto pela lei como crime culposo, torna penalmente responsável o agente, quando o fato é conseqüência da sua ação ou omissão.

$\mathrm{O}$ art. 64 do Decreto 70.050 dispõe que a aeronave civil acidentada, considerada irrecuperável, terá sua matrícula cancelada no Registro Aeronáutico Brasileiro.

Para evitar tal comunicação, e conseqüente inevitável cancelamento, determinadas oficinas costumam fazer "consertos" com tamanha falta de senso que uma simples faisca ou fagulha sobre a vaporização de combustivel seja suficiente para provocar uma explosão.

Por isso é que o parágrafo primeiro do aludido dispositivo subordina a reconstrução de uma aeronave considerada irrecuperável ao parecer favorável do órgão competente do Departamento de Pesquisas e Desenvolvimento, acrecentando:

"Após o término dos serviços de reconstrução, deverá ser submetida aos testes de homologação, como se fosse um tipo novo de aeronave; após a aprovação nesses testes, o interessado requererá ao Departamento de Aviação Civil, nova matrícula no Registro Aeronáutico Brasileiro, anexando o Certificado de Homologação."

Entre nós são mais raros do que era lícito supor, acórdãos a respeito de defeitos mecânicos em veículos terrestres e aéreos. 
O Terceiro Grupo de Câmaras Civis do Tribunal de Justiça de S. Paulo, teve ocasião de decidir, aos 15-03-1968, em embargos infringentes Rev. de Jurisprudência, vol. VII/236:

"Responsabilidade civil. Defeitos mecânicos em veículos não caracterizam força maior e nem caso fortuito. Obrigatoriedade de reparação de modo pleno, de tal forma que a situação do prejudicado seja restabelecida, da melhor forma possivel, no seu estado anterior."

Reconhecera o acórdão, pelo seu relator, Des. GOMES CORRÊA, que o defeito mecânico verificara-se na carburação e não se dera pelo fortuito ou força maior, uma vez que está diretamente ligado à conservação do veículo, aditando:

"Responsável pela reparação dos danos causados, em razão do ilícito, a Ré deve responder por todas as verbas necessárias à sua reparação e de modo pleno, de tal forma que a situação do prejudicado seja restabelecida, da melhor forma possível, no seu estado anterior."

Decidiu acórdão unânime da Segunda Câmara Civil do Tribunal de Alçada de S. Paulo de 30-03-1964:

"Ato jurídico. Defeito. Erro. Caminhão de 1947, permutado como se fora de 1951. Certificado de propriedade adulterado. Negócio anulado. Obrigação do autor da falsificação de reparar as perdas e danos. Ação procedente". (Rev. Tribunais, vol. 361/312)

\footnotetext{
O relator FRANCIS DAVIS, reconheceu estar provado $o$ engano.

Daí a ementa:
}

"Automóvel cujo certificado de propriedade apresenta falsificação do ano de fabricação demonstra ardil visando precisamente a iludir eventual comprador."

Poderão as agências distribuidoras de aviões e veículos terrestres, e os revendedores de aparelhos desses gêneros, usados, alegar que não têm responsabilidade, pois não são os fabricantes?

Claro que não, pois também contribuem para que os interessados os adquiram.

Orientação segura para o deslinde da dúvida iremos encontrar na regra, intuitiva, proposta por MARIANO FERNANDEZ MARTIN-GRANIZO, Los Daños y la Responsabilidad Objetiva en el Derecho Positivo Español, Pamplona, Aranzadi, 1972, pág. 176:

"Si suprimiendo mentalmente mi accion no se suprime contemporaneamente el resultado, en cuanto éste es directa e imediatamente provocado por una conducta estraña que 
se ha insertado en la mia, es que aquélla (mi acción) no ha intervenido sino mediata e incidentalmente en su causación."

Qualifica de um tanto imprecisa a denominação corrente de "culpa de terceiro" ou de "terceira pessoa", pois haverá casos em que tal atividade, embora produtora de um resultado lesivo, poderá não ser culposa nem simplesmente negligente, para tornar evidente que quando o resultado se produz como conseqüência direta da atividade alheia em mediata colaboração com a nossa, o problema se enraíza em determinar se existe "relação de causalidade" entre a nossa atividade e o resultado; e se, consequientemente, essa "atividade alheia" deve ou não excluir o "dever de indenizar" de nossa parte.

A responsabilidade civil está implícita no próprio gênero de atividade de quem vende ou serve de intermediário para a venda de aviões.

"De qualquer modo" - pondera PONTES DE MIRANDA, em seu Tratado, tomo LII, pág. 95 -, "alegado e provado que o dano resultou da atividade perigosa, a culpa do exercente está presumida. Ao demandado apresentar a prova de que não teve culpa, pois tomara todas as providências e medidas para que o dano não se desse."

Intuição clara da necessidade de "propor e adotar um sistema de fiscalização que evite a ocorrência, aqui, de tamanhos atentados à segurança de usuários e consumidores", que bem merecia ser ampliado muito além do objetivo visado, teve o deputado SIQUEIRA CAMPOS, em discurso publicado no Diário do Congresso Nacional de 07-08-1976, pág. 2.333, no qual transcreve notícia de Washington de multa de quatrocentos mil dólares, cerca de quatro e meio milhões de cruzeiros, imposta a uma conhecida indústria de âmbito mundial por se recusar a cumprir determinação do Governo norte-americano, no sentido de recolher cento e oitenta e seis mil carros com um defeito de segurança possivelmente perigoso.

\section{Das infrações}

As penalidades previstas no Título XIII serão aplicadas pela autoridade aeronáutica competente, de acordo com a gravidade das infrações, sem prejuízo nem impedimento da imposição, por outras autoridades, de penalidades previstas em leis ou regulamentos.

$\mathrm{O}$ art. 155 indica os casos de aplicação da pena de cassação do certificado de navegabilidade da aeronave, do certificado do tripulante ou da concessão ou da autorização de serviços aéreos; e o art. 156 os de pena de multa, concomitantemente ou não com a suspensão dos certificados. 
"Art. 158. Se a infração for cometida em conseqüência de ordem exorbitante ou indevida, do proprietário ou explorador da aeronave, devidamente comprovada, a responsabilidade de quem cumpriu a ordem fica atenuada ou eliminada, conforme o alcance da ação."

Os arts. 159 e 160 indicam os casos de detenção pela autoridade aeronáutica, e de interdição da aeronave.

Seguiu-se, aqui - consigna ALVINO LIMA - o sistema adotado pelo direito francês e alemão, quando tratam da responsabilidade em relação a terceiros, ilidindo-se tal responsabilidade tão-somente no caso de culpa da vítima.

\section{y. Das garantias de responsabilidade}

É matéria objeto dos arts. 122-127, o transportador ou explorador dará garantia de reparação dos danos pessoais e materiais de que for responsável nos termos do Código, na forma e limites nele estabelecidos, garantia que consistirá em seguro contratado com empresa idônea, na forma da legislação vigente, a cuja apresentação ou prova de vigência ficará condicionada a concessão ou validade do certificado de navegabilidade da aeronave.

Poder-se-á suspender, a qualquer momento, a validade do certificado de navegabilidade da aeronave ou aeronaves, quando o transportador ou explorador não provar que está executando, regularmente cláusulas do contrato de seguro a que estiver obrigado pela apólice respectiva.

LOUIS CARTOU, Droit Aérien, Paris, Presses Universitaires, 1963, demonstra que, em conseqüência de ser a aviação uma atividade que pode ser perigosa, é submetida a regras muito severas de utilização: é a razão por que o direito aéreo traduz o cuidado de garantir a segurança da navegação aérea, comportando numerosas disposições cujo conjunto constitui uma verdadeira regulamentação de polícia, em sentido amplo.

Acentuando que a técnica, caráter essencial da aviação, evolui rápida e profundamente, verifica que o direito aéreo traduz amplamente a complexidade técnica da aviação e a rapidez da sua evolução:

"O direito aéreo deve a esses liames com a técnica um dos seus caracteres menos felizes: a Instabilidade."

Justifica-se, pois, que para reparação dos danos que as aeronaves estrangeiras possam causar a pessoas e bens no território brasileiro, pretenda o art. 125 a apresentação de garantias pelo menos iguais, ou consideradas equivalentes, às exigidas para aeronaves nacionais ou, quando aplicável, as estabelecidas em Convenção Internacional de que o Brasil for parte, apresentação essa indispensável, para o sobrevôo do território brasileiro por aeronaves estrangeiras. 
Aquele que tiver direito a reparação do dano poderá exercer, nos limites da indenização que lhe couber, direito próprio sobre a garantia prestada pelo responsável.

Nas apólices de seguro de vida ou de seguro de acidente, não poderão os interessados excluir os riscos resultantes do transporte em aeronaves (arts. 126 e 127).

\section{Regras mais rigorosas a que estão sujeitas as atividades de perigo}

A doutrina tem ressaltado que, no exercício normal das profissōes, obriga a lei a certo grau de previdência e de diligência, sob pena de responder cada qual por seus atos.

Diligência e previdência que se acentua - será preciso dizê-lo? no desempenho das atividades consideradas perigosas. Por isso a diligência, em todas as atividades relacionadas com a aviação está sujeita a regras especiais, a particulares cautelas, tendentes a reduzir o perigo que as cercam.

A semelhança do nosso, o CC francês, no capítulo relativo aos delitos e aos quase-delitos, tem três dispositivos que solucionam a matéria.

$\mathrm{O}$ art. 1382, obrigando aquele por culpa do qual vem acontecer um dano decorrente de todo e qualquer ato, a repará-lo; o art. 1383 responsabilizando toda pessoa pelo dano que causou não somente por ato seu, mas ainda por sua negligência ou por sua imprudência, e o art. 1384, caput: toda pessoa é responsável não somente pelo dano que causou por ato seu próprio, mas ainda por aquele que foi causado por ato de pessoa pela qual devia responder, ou por coisas que estão sob a sua guarda.

Nenhum outro Código atingiu, nesse particular, o poder de síntese do mexicano:

“1913. Quando uma pessoa faz uso de mecanismos, instrumentos, aparelhos ou substâncias perigosas por si mesmas, pela velocidade que desenvolvem, por sua natureza explosiva ou inflamável, pela energia da corrente elétrica que conduzam ou por causas análogas, está obrigada a responder pelo prejuízo que causar, mesmo que não obreilicitamente, a não ser que demonstre que esse prejuízo foi produzido por culpa ou negligência inexcusável da vítima."

Manda o Decreto $\mathrm{n}^{\circ}$ 57.055, de 11-10-1965, que aprova o Regulamento para o Serviço de Investigação e Prevenção de Acidentes Aeronáuticos; em seu art. $2^{\circ}$, caput, aos Comandantes, Diretores ou Chefes de Organizações do Ministério da Aeronáutica, Presidentes e Diretores de Empresas de Transporte Aéreo, de Aeroclubes, todos os 
demais operadores, fabricantes de aeronaves e representantes de fabricantes de aeronaves nacionais ou estrangeiras, bem como todas as pessoas envolvidas na operação ou no apoio de aeronaves considerem a prevenção de acidentes aeronáuticos como requisito inerente às suas funções e responsabilidades. Todos deverão manter um contínuo e efetivo programa de prevenção de acidentes aeronáuticos com a finalidade de evitar perdas de vidas ou de material.

O Serviço de Investigação e Prevenção de Acidentes (SIPAER) tem a missão de orientar e supervisionar a prevenção de acidentes aeronáuticos e executar as investigações dos mesmos (art. 4, caput), aditando:

“§ 1" Dessa forma toda ocorrência que sobrevier a uma aeronave, da qual resultam danos pessoais ou materiais, será objeto de investigações por parte do SIPAER, através da cadeia de autoridades que o integram."

Quando o curso da investigação revelar indício de crimes ou de contravenção - art. $5^{\circ}$ caput —, a autoridade que determinou a investigação ou a autoridade superior mandará instaurar, em paralelo ou posteriormente, o Inquérito Policial-Militar, a Sindicância ou o Inquérito Administrativo competente.

O Código Brasileiro do Ar comina, no art. 155, pena de cassação do certificado de navegabilidade da aeronave, do certificado do tripulante ou da concessão de autorização de serviços aéreos, entre outros casos,

a . no de perda do nível de aptidão técnica ou de condições físicas;

b. procedimentos ou práticas, no exercício das funções, que revelem falta de idoneidade profissional para o exercício das prerrogativas de certificado de habilitação técnica.

Continua pois da mais completa atualidade o reconhecimento de CESARE SAVOIA, um dos primeiros a versar $L a$ Responsabilitò Civile del Vettore Aereo, Roma, Athenaeum, 1928, pág. 22, de que todos aqueles que pretendam colocar no ar o seu aparelho devem obter a prévia autorização da autoridade competente, mediante a outorga do certificado de navegabilidade.

Responde afirmativamente à pergunta se o certificado de navegabilidade pode servir para pré-constituir uma prova de diligência, que exclua a culpa, em caso de sinistro.

Cs 67 artigos do Decreto $\mathrm{n}^{\circ}$ 70.050, de 25-01-1972, que aprova o Regulamento para o referido serviço (SIPAER) revelam a preocupação primordial da segurança de vôo, reafirmando e desenvolvendo o art. $7^{\circ}$ espírito do art. $2^{\circ}$ do já citado Decreto 57.055.

Acrescenta o art. 11 que a autoridade que der a solução da investigação deve remeter uma cópia do Relatório Final de Acidente à 
Inspetoria Geral da Aeronáutica, a quem competirá a difusão dos ensinamentos aos interessados, e, chegando ao ponto:

"Art. 12. Quando no curso de uma investigação de acidente aeronáutico houver indícios de crime ou contravenção, a autoridade que determinou a investigação mandará instaurar, em paralelo ou posteriormente, o Inquérito Policial Militar, Inquérito Administrativo ou Sindicância ou solicitará à autoridade civil a abertura de Inquérito Policial, conforme esses indícios sejam de natureza militar ou comum.

$\S 1^{\circ}$ Ressalvados os casos previstos na legislação federal, a apuração da responsabilidade criminal, surgida em investigação de acidente aeronáutico, ocorrido com a aeronave civil, é da alçada da Autoridade Policial do local do acidente ou da Polícia Federal, quando for o caso."

Exige $o$ art. 46 que o operador de aeronave não pertencente ao Ministério da Aeronáutica, em primeiro lugar, notifique pelo meio mais rápido o acidente aeronáutico ocorrido com a sua aeronave aos órgãos que indica, e, em segundo, que evite sejam a aeronave avariada ou os destroços removidos, ou tocados de qualquer forma, enquanto não chegar a autoridade investigadora.

$\mathrm{O}$ art. $7^{\circ}$ do aludido decreto atribui a prevenção de acidentes aeronáticos, a todas as pessoas envolvidas na operação ou no apoio de aeronaves, regra de ordem pública.

Compendiando a lição da doutrina e da jurisprudência, propunha o anteprojeto do Código das Obrigações CAIO MÃRIO DA SILVA PEREIRA, na Seção III, Responsabilidade independente de Culpa, Título IX, Responsabilidade Civil:

"Art. 935: Aquele que cria um perigo em razão da sua atividade ou profissão, pela natureza delas, ou pelos meios empregados, está sujeito à reparação do dano que causar, salvo se provar que adotou todas as medidas idôneas a evitá-los".

\section{Cálculo da indenização}

Varia, de caso para caso, o montante da indenização a ser paga.

No cálculo de abalroamento de veículos, como danos materiais, deverão, no entanto, ser levados em conta dados diversos.

No caso de danos pessoais o Código Criminal de 1830 já preceituava, no art. 22, que "A satisfação será sempre a mais completa que for possível, sendo no caso de dúvida, a favor do ofendido. Para este fim, o mal, que resultar à pessoa e bens do ofendido, será avaliado em todas as suas partes e conseqüências". 
A legislação posterior parece como que atenuar a severidade muito justa, aliás - do dispositivo.

A Lei $n^{\circ}$ 2.681, de 07-12-1912 estabelece, nos casos de:

morte: que a responsabilidade será por todas as despesas e indenização a todos aqueles aos quais a morte do viajante privar de alimento, auxílio ou educação;

lesão corporal ou deformidade: de acordo com as circunstâncias, especialmente a invalidade para o trabalho ou profissão habitual, além das despesas com o tratamento e os lucros cessantes, uma indenização conveniente (art. 21);

ferimento: indenização equivalente às despesas do tratamento e aos lucros cessantes durante ele.

$\mathrm{Na}$ mesma linha de pensamento, no caso de morte, manda o CC pagar despesas com o tratamento da vítima, seu funeral e o luto da família e na prestação dos alimentos às pessoas a quem o defunto os devia.

No caso de ferimento ou outra ofensa à saúde determina o art. 1538 que o ofensor indenize o ofendido das despesas do tratamento e dos lucros cessantes até o fim da convalescença.

Cominava ainda uma multa, a ser duplicada no caso de resultar do ferimento aleijão ou deformidade, de que não há cogitar, uma vez que o Código Penal vigente não a determina.

Em se tratando de mulher solteira ou viúva, ainda capaz de casar, a indenização consistirá num dote $\left(\S 2^{\circ}\right)$.

Finalmente, o art. 1539 limita-se a dispor que "Se da ofensa resultar defeito pelo qual o ofendido não possa exercer o seu ofício ou profissão, ou se lhe diminua o valor do trabalho, a indenização, além das despesas do tratamento e lucros cessantes até ao fim da convalescença, incluirá uma pensão correspondente à importância do trabalho, para que se inabilitou, ou da depreciação, que ele sofreu."

Não escapou à perspicácia de CLóVIS BEVILĀQUA, a discrepância com o critério anterior, muito mais coerente na sua menor benevolência, uma vez que o que se cogita é justamente "Da liquidação das obrigações resultantes de atos ilícitos".

Mas procura justificar que o dispositivo de 1830 havia sido haurido em BENTHAM e seria uma recomendação ao juiz do que um preceito imperativo, antes a síntese de uma doutrina do que uma regra legal, que se possa aplicar aos casos concretos sem o perigo do arbítrio.

E se a vítima já recebe uma pensão pelo Instituto de Previdência ou instituição análoga? 
É claro que não se irá descontar a respectiva importância da indenização decorrente do desastre.

O pagamento da pensão - teve oportunidade de encarecer acórdão da $5^{\text {a }}$ Câmara do TJ do Estado de São Paulo, RT 197/270, que pode ser tomado como padrão - resulta da própria contribuição da vítima ao Instituto, e é descontado do seu salário, mensalmente, para formar o fundo de providência e ampará-lo em caso de enfermidade. A jurisprudência é tranqüila nesse sentido: RT 200/380, 203/181, $251 / 265$ etc.

\section{Na lição de EDUARDO ESPINOLA:}

$1^{0}$ - Nos desastres ou acidentes ferroviários, aplicam-se às lesões dos passageiros e aos danos das coisas transportadas os dispositivos da Lei $\mathrm{n}^{\circ}$ 2.681, de 1912 (culpa contratual).

$2^{\circ}$ - Nos mesmos desastres ou acidentes, aplicam-se, aos infortúnios dos transeuntes e às deteriorações das coisas estranhas ao contrato de transporte, os dispositivos dos arts. 159, 160, 1.118 e segs. CC (culpa extracontratual).

$3^{\circ}$ - Nos desastres ocorridos em bondes, ônibus, etc., aplica-se o art. $1.056 \mathrm{CC}$, que, em sua generalidade, abrange a regra do art. 102 do CCom, aos males que sofrem os passageiros ou as coisas transportadas (culpa contratual).

$4^{\circ}$ - Nos mesmos desastres de bondes, etc. aplicam-se os dispositivos do CC, arts. 159, 160, 1.518 e seguintes, quando ofendida seja pessoa que não tenha a qualidade de passageiro, ou coisa que se não encontre no veículo, que não seja transportada.

Terão que ser considerados ainda os seguintes elementos:

- desvalorização do veículo (RT 200/185);

- estadia do mesmo em garagem, estaleiro, hangar, etc.;

- despesas de condução. Quem possui um carro, por exemplo, para seu uso, para levar os filhos à escola, para as necessidades da mulher, não é obrigado a privar-se dessa comodidade;

- tratando-se de motorista ou de piloto profissional, os dias em que ficar impossibilitado de trabalhar;

- honorário de advogado: RT 291/700, 290/432, 200/185, etc.

No transporte de carga ou bagagem, salvo convenção entre as partes, dispõe o Código do Ar, art. 103 , $\S 1^{\circ}$, a responsabilidade do transportador se limita à quantia calculada por quilo, à base de $1 / 3$ do maior salário mínimo vigente no País.

$\S 2^{\circ}$ Quanto à bagagem e objetos que o passageiro conservar sob a sua guarda, a responsabilidade do transportador não excederá de quatro vezes o maior salário mínimo vigente no País. 
"Art. 104. O transportador responde perante os tripulantes da aeronave e demais empregados que nela viajarem a seu serviço, ou perante os respectivos beneficiários, nos mesmos casos, segundo o mesmo critério e sob o mesmo regime de garantias estabelecidas com relação ao passageiro, por uma indenização de limite igual à que lhes seria devida se passageiros fossem deduzido o valor da indenização que receberem, ou que teriam direito a receber pela legislação de acidentes de trabalho."

Comparando-se o texto atual com os arts. 90 e 93 do anterior. Código verifica-se a eliminação da eventualidade do dano ter sido causada por culpa da pessoa lesada, caso em que era admitida a hipótese de exclusão ou atenuação da responsabilidade do transportador, mantido o anterior art. 93 no atual:

"Art. 106. Quando o dano resultar de dolo do transportador ou de seus prepostos, nenhum efeito terão os artigos deste Código que excluam ou atenuem a responsabilidade."

Confrontando o dispositivo com o correspondente da Convenção de Varsóvia nota OCTANNY SILVEIRA DA MOTTA que o legislador brasileiro sintetizou, nessa fórmula breve, o conteúdo de duas alíneas do art. 25 daquela Convenção, fugindo, entretanto, a equiparar a culpa ao dolo, para efeito de tornar ilimitada a responsabilidade do transportador aéreo, que havia motivado críticas severas.

Sustenta que ao dolo do transportador, só se podem ligar conseqüências após provado o mesmo dolo. $\mathrm{E}$ à tentativa de produção dessa prova, o transportador há de estar legitimamente autorizado a opor toda e qualquer defesa que a norma faça permissível pela razão de que oportunidade para fazê-lo apresenta-se no decurso do processo em cujo encerramento o dolo seu virá, acaso, a ser reconhecido. Entendimento diverso permitiria retirar consequiências do dolo do transportador antes do mesmo provado.

Diante da possibilidade, já admitida no art. 91 do Código revogado, de transportador e usuário estipularem, convencionalmente, que o montante de indenização eventualmente devida seja superior ao previsto em lei, indaga se o transportador que aja com dolo poderá ser admitido a não indenizar para além da quantia convencionalmente fixada.

Demonstra que, em caso de dolo próprio ou de prepostos, o transportador não poderá invocar montante de indenização convencionalmente fixado e ater-se a ele, fugindo a cobrir quaisquer prejuízos que o excedam. A sanção prevista pelo art. 25 da Convenção - e pelo art. 106 de nosso Código - é a da ilimitação e, assim, o transportador ver-se-á compelido a compensar totalmente o prejuízo causado por dolo, não só próprio, mas ainda de prepostos seus.

"Art. 107 O recebimento de bagagem ou carga, sem protestos do destinatário faz presumir, salvo prova em contrário, que foi entre- 
gue em bom estado e de conformidade com o documento de transporte."

"Art. 108. No caso de transporte executado sucessivamente por vários transportadores, cada transportador que receber passageiro, bagagem ou carga, ficará sujeito às regras deste Código e considerado parte no contrato de transporte.

$\S 1^{\circ}$ O passageiro, ou os que o sucederem nos seus direitos, só terão direito de ação contra o transportador que haja efetuado o transporte, no curso do qual se tiver produzido o acidente ou atraso salvo se, por estipulação expressa, o primeiro transportador assumir a responsabilidade em todo o percurso da viagem.

$\S 2^{\circ} \quad$ Em se tratando de bagagem ou carga, o expedidor terá ação contra o primeiro transportador, e o destinatário, a quem couber direito a entrega, contra o último. Um e outro poderão acionar o transportador que haja efetuado o transporte durante o qual tiver ocorrido a destruição, perda, avaria ou atraso. Esses transportadores serão solidariamente responsáveis ante o expedidor e o destinatário." 